\title{
Pengukuran Kesuksesan Implementasi E-Learning dengan Metode TAM dan UTAUT
}

\author{
Ockhy Jey Fhiter Wassalam ${ }^{\# 1}$, Rusydi Umar ${ }^{* 2}$, Anton Yudhana \#3 \\ ${ }^{\#}$ Magister Teknik Informatika, Universitas Ahmad Dahlan, Yogyakarta Jl. \\ Prof. Dr. Soepomo, SH, Warungboto, Umbulharjo, Yogyakarta \\ 1ockhyuad3@gmail. com \\ ${ }^{2}$ rusydi umarerocketmail.com \\ *Program Studi Teknik Elektro,Universitas Ahmad Dahlan, Yogyakarta \\ Prof. Dr. Soepomo, SH, Warungboto, Umbulharjo, Yogyakarta \\ 3eyudhana@ee. uad.ac.id
}

\begin{abstract}
Abstrak - Penelitian ini bertujuan untuk mengetahui tingkat pengukuran kesuksessan terhadap implementasi sistem e-learning pada Universitas ZZP Yogyakarta dengan menggunakan metode TAM (Technology Acceptance Model) dan metode UTAUT (Unified Theory of Acceptance and Use of Technology). Penelitian ini menggunakan semua variabel yang ada pada kedua metode TAM dan UTAUT. Dalam melakukan pengukuran data yang dianalisis pada penelitian ini menggunaka kuisioner yang disebarkan kepada 30 responden yaitu Mahasiswa/i Fakultas Ekonomi di Universitas ZZP Yogyakarta. Data yang dianalisis dihitung dalam bentuk kuantitatif analisis interval menggunakan skala likert dan kemudian dilakukan analisa menggunakan metode TAM dan UTAUT untuk mengukur tingkat kesuksesan implementasi e-learning. Berdasarkan hasil penelitian menunjukan pengukuran kesuksesan terhadap implementasi e-learning dengan metode TAM dan UTAUT persentase sebesar $66,75 \%$ (TAM), $69,66 \%$ (UTAUT) menyatakan sukses dan persentase 33,25\% (TAM), 30,34\% (UTAUT) menyatakan tidak sukses. Sehingga kesimpulan dari pengukuran kesuksesan menggunakan ke-2(dua) metode dengan persentase $68,03 \%$ menyatakan dapat diterima, dan $31,07 \%$ responden tidak menyatakan kesuksesan terhadap implementasi e-learning.
\end{abstract}

Kata kunci - Kesuksesan, Pengukuran, E-learning, TAM, UTAUT

\section{Pendahuluan}

Saat ini Teknologi informasi dan komunikasi telah semakin berkembang membawa perubahan baik dalam aspek kehidupan. Berbagai metode atau cara telah dilakukan untuk menggunakan teknologi tersebut baik secara efektif dan efesien[1][2][3].

Teknologi informasi juga menawarkan pontesi substansi bagi organisasi untuk meningkatkan kinerjanya. Dalam peningkatan kinerja tersebut seringkali tak tercapai karena kurang kesediaan pengguna (user) untuk menerima dan menggunakan sistem yang sudah ada. Pernerimaan teknologi informasi merupakan syarat yang utama kesuksesan implementasi teknologi informasi[4][5]. Karena pentingnya masalah ini, penjelasan penerimaan pengguna atas teknologi informasi telah menjadi isu yang sangat lama diteliti dalam bidang manajemen sistem informasi[6]. Keputusan untuk mengadopsi suatu teknologi informasi ada ditangan manajer, tetapi keberhasilan penggunaan teknologi informasi tersebut tergantung pada penerimaan dan penggunaan setiap individu pemakainya[7]. Perilaku pemakai terbentuk dari sikap dan persepsi pemakai terhadap teknologi informasi tersebut. Salah satu upaya untuk memahami perilaku pengguna teknologi informasi adalah melalui kajian dan penelitian terhadap teori atau model adopsi teknologi informasi. Berbagai teori perilaku banyak digunakan untuk mengkaji proses adopsi teknologi informasi oleh end-user (pengguna akhir), diantaranya Theory of Reason Action (TRA), Theory of Planned Behavior (TPB), Technology Acceptance Model (TAM) dan Unified Theory Of Acceptance and Use Of Technology (UTAUT).

$E$-learning adalah teknologi komunikasi dan intensitas pengguna informasi dalam proses belajar mengajar. $E$ learning meliputi pembelajaran online, pembelajaran virtual, pembelajaran terdistribusi, pembelajaran berbasis web. Pada dasarnya, e-learning hanya untuk proses pendidikan dengan memanfaatkan teknologi informasi dan komunikasi sebagai media pembelajaran dan mengajar secara tidak langsung[8].

Maka dengan model penerimaan teknologi dianggap paling tepat untuk digunakan. Motode TAM(Technology Acceptance model) dan UTAUT (unified theory of acceptance and use of techology) banyak digunakan oleh penelitian dalam mengukur kesuksesan penerapan sistem informasi berdasarkan keinginan pengguna dalam menggunakan sistem informasi tersebut[9]. TAM juga dikembangkan untuk menjelaskan prilaku pengguna sistem informasi atau teknologi. Metode ini menepatakan faktor sikap dan tiap-tiap prilaku pemakai dengan konstruk yaitu persepsi kegunaan (percieved usefulness), 
kemudahan pengguna (percieved ease of use) dan kondisi nyata pengguna sistem (actual system usage[10][11][12]). Sedangkan metode UTAUT paling banyak digunakan dalam penelitian pengukuran kesuksesan penerapan sistem informasi yang berkaitan dengan akademik. Salah satu model penerimaan teknologi yang banyak digunakan adalah unified theory of acceptance and use of techology (UTAUT). UTAUT model sebagai sintesis komprensif sebelum penelitian penerimaan teknologi. UTAUT model yang telah memahami perkembangan dari sebelumnya, memiliki empat kunci konstruk, yaitu: harapan kinerja (performance expectancy), harapan usaha (effort expectancy), pengaruh sosial (social influence), dan kondisi fasilitas (facilitating conditions) terhadap niat (behavior intention) untuk penerimaan teknologi (use technology)[13][14].

Tujuan penelitian adalah untuk memperoleh pemahaman yang lebih baik terhadap penerimaan perbandingan kesuksesan sistem e-learning oleh mahasiswa di Universitas ZZP Yogyakarta. Penerapan sistem e-learnig di Universitas ZZP Yogyakarta, telah berjalan selama 3 tahun, banyak dalam penerapannya ternyata masih terdapat beberapa kendala, terutama yang terkait dalam aspek penerimaan dan penggunaan sistem $e$ learning oleh para penggunanya. Penggunaan sistem $e$ learning, bertujuan untuk membantu perbaikan dan penambahan pada sistem pengajaran para dosen terhadap mahasiswa.

Berdasarkan permasalah yang terdapat diatas, maka dilakukan penelitian yang berjudul Perbandingan kesuksesan Implementasi e-learning Dengan metode TAM (Technology Acceptance model) dan UTAUT (unified theory of acceptance and use of techology). Untuk mengetahui besarnya tingkat penerimaan dalam penggunaan sistem e-learning pada Universitas ZZP Yogyakarta.

\section{Metode Penelitian}

Metode penelitian pada penelitian ini adalah pendeketan kuantitatif. Penelitian ini bersifat kuantitatif digunakan untuk penelitian populasi yang luas dan sampel yang besar maka digunakan rancangan survey dengan menjabarkan respon pengguna akhir dalam perbandingan kesuksesan implementasi e-learning dengan metode TAM dan UTAUT pada Universitas ZZP Yogyakarta. Penelitian kuantitatif dengan menggunakan teknik pengumpulan data yang utama adalah kuesioner dan pendukungnya data mahasiswa beserta wawancara [15][16].

\section{A. Technology Acceptance Model (TAM)}

Technology Acceptance Model (TAM) dibuat khusus untuk pemodelan adopsi pengguna sistem informasi. Tujuan utama TAM adalah untuk mendirikan dasar penelusuran pengaruh faktor eksternal terhadap kepercayaan, sikap (personalisasi), dan tujuan pengguna komputer[17]. TAM menganggap bahwa dua keyakinan variabel prilaku utama dalam mengadopsi sistem informasi, yaitu persepsi pengguna terhadap manfaat dan persepsi pengguna tehadap penggunaan. Perceived usefulness diartikan sebagai tingkat dimana seseorang percaya bahwa menggunakan system tertentu dapat meningkatkan kinerjanya, dan perceived ease of use diartikan sebagai tingkat dimana seseorang percaya bahwa menggunakan system tidak diperlukan usaha apapun.

Konsep TAM yang dikembangkan menawarkan sebuah teori sebagai landasan untuk mempelajari dan memahami perilaku pemakai dalam menerima dan menggunakan sebuah sistem informasi. Perluasan konsep TAM diharapkan akan membantu memprediksi sikap dan penerimaan seseorang terhadap teknologi dan dapat memberikan informasi mendasar yang diperlukan mengenai faktor-faktor yang menjadi pendorong sikap individu tersebut[18].

TAM terdiri dari dua konstruk utama yaitu kemudahan penggunaan yang dipersepsikan (perceived use of use) dan manfaat dipersepsikan (perceived usedfulness) yang menentukan intense perilaku (behavioral intention) seseorang untuk menggunakan teknologi. Intense perilaku adalah seberapa besar keinginan seseorang untuk melakukan tindakan tertentu[19]. Kegunaan persepsian (perceived usefulness) dan kemudahan penggunaan persepsian (perceived easy of use) memberikan pengaruh pada behavioral intention, tetapi tidak sebaliknya. Pemakaian teknologi akan mempunyai behavioral intention menggunakan teknologi (minat pelaku) jika sitem atau teknologi bermanfaat dan mudah digunakan. Jika sistem sangat bermanfaat, mudah atau tidak penggunaannya akan tetap digunakan[20]. Berikut model dasar TAM dapat dilihat pada Gambar 1.

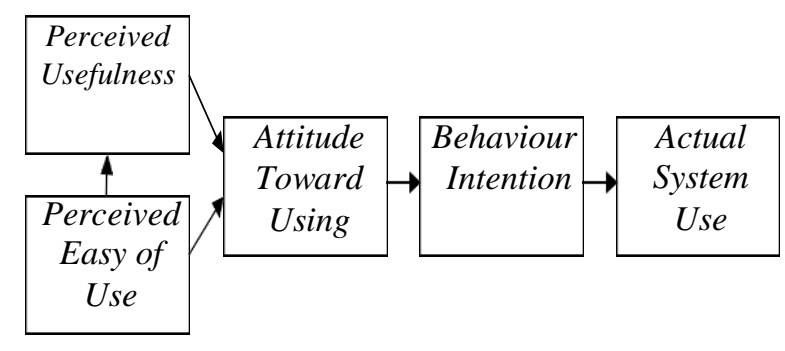

Gambar 1. Kerangka penelitian TAM

\section{B. Unified Theory Of Acceptance and Use Of Technology}

Unified Theory of Acceptance and Use of Technology yang dikembangkan Model ini delapan model penerimaan teknologi yang telah dikembangkan sebelumnya. Delapan model tersebut antara lain theory reasoned action (TRA), technology acceptance model (TAM), motivational model (MM), theory of planned behavior (TPB), combined tam and tpb, model of $p c$ utilization (MPCU), innovation diffusion theory (IDT) dan social cognitive theory (SCT)[21][22] 
Model UTAUT memiliki empat kontruk utama yang memainkan peran penting sebagai determinan langsung dari behavioral intention dan use behavior yakni performance expectancy, effort expentancy, social influence dan facilitating conditions. Disamping itu terdapat empat moderator yaitu gender, age, experience dan voluntariness of use, yang diposisikan untuk memoderasi dampak dari konstruk-konstruk pada behavioral intention dan use behavior[23][24]. Dapat dilihat pada Gambar 2.

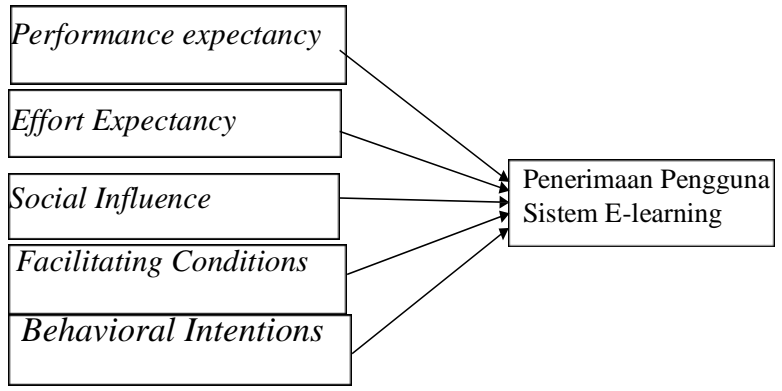

Gambar 2. Kerangka penelitian UTAUT

Bentuk penelitian ini menggunakan analisi interval data kuantitatif dengan skala likert untuk meneliti variabelvariabel kedua metode TAM dan UTAUT dengan memberikan kuesioner kepada responden yaitu mahasiswa/i Fakultas Ekonomi Universitas ZZP Yogyakarta.

Deskripsi data kuesioner yang dibagikan kepada responden yaitu mahasiswa berjumlah 30 kuesioner dan 30 mahasiswa yang menjadi target penelitian di kelompokkan berdasarkan jenis kelamin ditunjukkan pada Tabel 1.

TABEL I

RESPONDEN BERDASARKAN JENIS KELAMIN

\begin{tabular}{|l|l|l|l|}
\hline No & Jenis kelamin & Frekuensi & Persentase \% \\
\hline 1 & Laki-laki & 13 & 43 \\
\hline 2 & Perempuan & 17 & 57 \\
\hline \multicolumn{2}{|l|}{ Jumlah } & 30 & 100 \\
\hline
\end{tabular}

Berdasarkan Tabel 1, diketahui hasil dari rekap data kuesioner maka jenis kelamin laki-laki sebanyak 13 orang dengan persentase sebesar 43\%, dan jenis kelamin perempuan sebanyak 17 orang dengan persentase sebesar 57\%. Dapat diambil kesimpulan jenis kelamin yang mendominasi dalam pengisian kuesioner adalah perempuan sebanyak 17 orang dengan persentase $57 \%$.

\section{Tahapan penelitian}

Tahapan penelitian ini merupakan tahapan yang akan dilakukan peneliti untuk mempermudah dalam melakukan penelitian. Desain perbandingan kesuksesan implementasi e-learning dengan metode TAM dan UTAUT. Dapat dilihat pada Gambar 3.

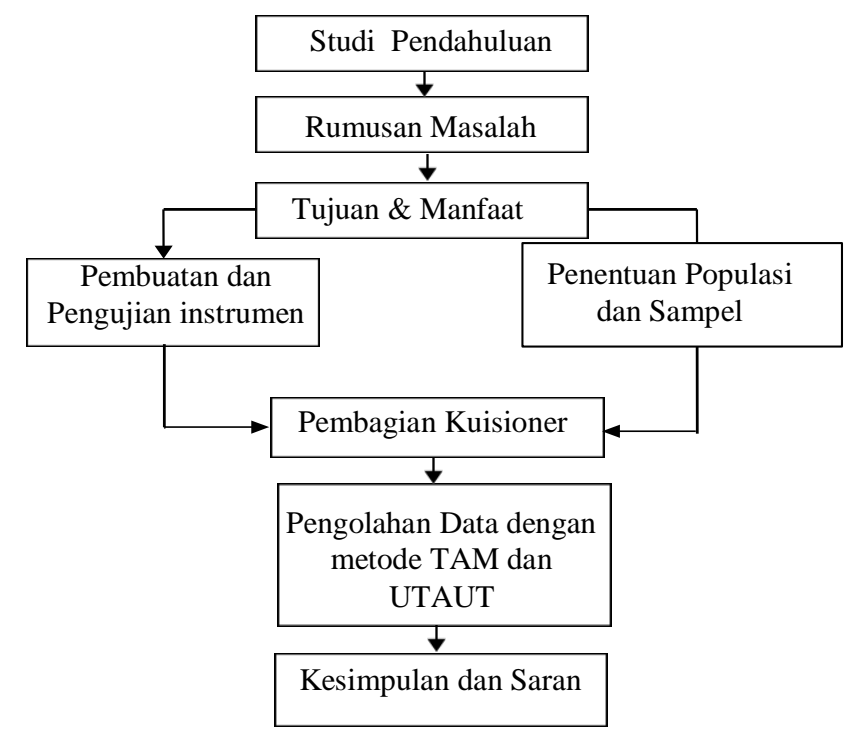

Gambar 3. Kerangka Tahap Penelitian

\section{HASIL DAN PEMBAHASAN}

\section{A. Deskripsi Data Responden}

Pengujian data dalam penelitian ini menggunakan Skala likert dilakukan untuk mengetahui lebih besar mana penerimaan kesuksesan sistem e-learning pada mahasiswa/i Fakultas Ekonomi Universitas ZZP Yogyakarta. Berikutnya adalah langkah-langkah pengumpulan data dalam skala likert sebagai berikut :

Instrumen berupa kuesioner penelitian dirancang dengan skala likert yang terdiri dari 5 skala yaitu $1=$ "sangat tidak setuju", 2= "tidak setuju", 3= "cukup setuju" 4= "setuju" dan 5= "sangat setuju" (likert scale). Teknik analisis data yang digunakan dalam penelitian ini adalah teknik analisis statistik deskriptif dengan langkahlangkah yang dilakukan sebagai berikut[25][26]

1. Menentukan besarnya skor kriterium sesuai dengan hasil yang didapat dari pengolahan data sebelumnya. Skor kriterium (SK) adalah skor ideal yang dicapai dalam sebuah penelitian. Apabila diasumsikan seluruh responden (berjumlah 100) yang ditetapkan memilih jawaban angka terendah yaitu 1 untuk 1 pertanyaan, maka skor yang terendah adalah 100. Apabila diasumsikan seluruh responden yang ditetapkan memilih angka tertinggi yaitu 5 untuk 1 pertanyaan, maka skor tertinggi adalah 500. Skor tertinggi inilah yang disebut skor kriterium. Cara mendapatkan skor kriterium ini adalah dengan menggunakan rumus sebagai berikut :

$\sum \mathrm{SK}=$ Skor tertinggi tiap item pertanyaan $\mathrm{x}$ jumlah item pertanyaan $\mathrm{x}$ jumlah responden.

2. Kemudian, ditentukan skor total dari hasil pengumpulan data yang sudah dilakukan. Skor total hasil pengumpulan data disimbolkan dengan dengan $\Sigma \mathrm{SH}$.

3. Setelah skor kriterium ( $\left.\sum \mathrm{SK}\right)$ dan skor total hasil pengumpulan data $\left(\sum \mathrm{SH}\right)$ didapatkan, maka dicarilah 
besarnya presentase (P) jawaban reponden dengan menggunakan rumus sebagai berikut :

$$
\mathrm{P}=\frac{\sum \mathrm{SH} \times 100 \%}{\sum \mathrm{SK}}
$$

Keterangan :

$\mathrm{P}=$ Persentase jawaban responden

$\Sigma \mathrm{SK}=$ Skor kriterium

$\Sigma \mathrm{SH}=$ Skor total hasil pengumpulan data

4. Langkah terakhir adalah menentukan rentang hasil berdasarkan skor kriterium dan persentase yang didapatkan untuk kemudian dibandingkan dengan skor hasil pengumpulan data. Rentang (range) hasilnya dapat disajikan pada Tabel 2 berikut ini :'

TABEL II

KATEGORI JAWABAN RESPONDEN

\begin{tabular}{|l|l|}
\hline Keterangan Angka & Kriteria Interpretasi Skor \\
\hline $0 \%-20 \%$ & Sangat Tidak Setuju \\
\hline $21 \%-40 \%$ & Tidak Setuju \\
\hline $41 \%-60 \%$ & Cukup Setuju \\
\hline $61 \%-80 \%$ & Setuju \\
\hline $81 \%-100 \%$ & Sangat Setuju \\
\hline \multicolumn{2}{|l|}{ Skala pengukuran setiap alternatif jawaban }
\end{tabular}
menggunakan skala likert yang merupakan skala yang biasa digunakan untuk mengukur sikap, pendapat, dan persepsi seseorang (Sugiyono, 2010: 134). ${ }^{[8]}$ Skala likert yang digunakan adalah 5 skala. Untuk keperluan analisis maka jawaban diberi skor, dapat dilihat pada Tabel 3.

TABEL III

SKALA LIKERT

\begin{tabular}{|c|c|c|}
\hline No & Alternatif Jawaban & Skor Pernyataan \\
\hline 1 & Sangat Tidak Setuju (STS) & 1 \\
\hline 2 & Tidak Setuju (TS) & 2 \\
\hline 3 & Cukup Setuju (CS) & 3 \\
\hline 4 & Setuju (S) & 4 \\
\hline 5 & Sangat Setuju (SS) & 5 \\
\hline
\end{tabular}

\section{B. Analisis Data}

Gambaran umum responden yang menjadi objek penelitian ini diklasifikasikan berdasarkan umur, jenis kelamin, pengalaman dan kesukarelaan menggunakan sistem e-learning pada Universitas ZZP Yogyakarta.

1. Responden Berdasarkan Umur Berdasarkan usia responden pengguna akhir sistem e-learning Universitas ZZP Yogyakarta. dapat diketahui bahwa responden yang mengisi kuesioner penelitian ini mengenai sistem $E$ learning pada Universitas ZZP Yogyakarta dari usia 1924 sebanyak 27 orang atau jika dipersentasekan sebesar
90\%, dari usia 25-29 sebanyak 2 orang jika dipersentasekan sebesar 7\%, dan usia 30-35 sebanyak 1 orang jika dipersentasekan sebesar 3\%. Maka dapat disimpulkan bahwa hasil penelitian ini dipengaruhi oleh responden yang berusia 19-24 tahun. Data responden berdasarkan umur.

2. Responden Berdasarkan Pengalaman Menggunakan Sistem E-Learning Setelah melakukan persentase berdasarkan umur, bahwa responden yang sudah berpengalaman menggunakan sistem e-learning sebanyak 28 orang dengan persentase $93 \%$ dan yang tidak berpengalaman menggunakan sistem e-learning sebanyak 2 orang dengan persentase $7 \%$. Maka dapat dilihat responden yang sudah berpengalaman lebih mendominasi yaitu sebanyak 28 orang dari 30 sampel yang dibutuhkan.

3. Responden Berdasarkan Manfaat Menggunakan Sistem E-Learning, dapat diketahui responden yang mengisi kuesioner ini di dominasi oleh responden yang mendapatkan manfaat dalam menggunakan sistem $e$ learning yaitu sebanyak 28 orang dengan persentase $93 \%$ dan yang tidak mendapatkan manfaat menggunakan sistem e-learning adalah sebanyak 2 orang dengan persentase $7 \%$. Data responden berdasarkan kesukarelaan menggunakan sistem e-learning.

\section{Deskripsi Variabel Penelitian}

Metode TAM menggunakan 4 variabel untuk melakukan pengukuran penerimaan kesuksesan dengan kuesioner sesuai dengan variabel pertanyaan sebagai berikut :

1. Variabel Kebermanfaatan menggunakan terdiri dari 2 butir pertanyaan, berikut ini adalah tabel distribusi frekuensi variabel perilaku menggunakan berdasarkan hasil pengumpulan kuesioner yang sudah diolah terdapat pada Tabel 4 berikut ini :

TABEL IV

PERTANYAAN PERSEPSI KEBERMANFAATAN

\begin{tabular}{|c|l|c|c|c|c|c|}
\hline No & $\begin{array}{l}\text { Persepsi kebermanfaatan } \\
\text { (Perceived Usefulnes) }\end{array}$ & $\begin{array}{c}\text { STS } \\
1\end{array}$ & $\begin{array}{c}\text { TS } \\
2\end{array}$ & $\begin{array}{c}\text { CS } \\
3\end{array}$ & $\begin{array}{c}\text { S } \\
4\end{array}$ & $\begin{array}{c}\text { SS } \\
5\end{array}$ \\
\hline 1 & $\begin{array}{l}\text { Sistem E-learning lebih efesien } \\
\text { dari pada belajar formal }\end{array}$ & 0 & 3 & 8 & 16 & 3 \\
\hline 2 & $\begin{array}{l}\text { Sistem E-learning mempercepat } \\
\text { dalam kegiatan belajar } \\
\text { mengajar }\end{array}$ & 0 & 0 & 9 & 11 & 10 \\
\hline
\end{tabular}

Maka dilakukan analisis dengan metode likert untuk mendapatkan range kategori. Dari perhitungan metode likert didapatkan range kategori variabel niat untuk berperilaku, adapun range kategorinya dapat dilihat pada Tabel 5.

TABEL V

RANGE VARIABEL KEBERMANFAATAN

\begin{tabular}{|l|l|l|l|lr|r|}
$20 \%$ & $40 \%$ & $60 \%$ & $\mathbf{7 6 , 6 6 \%}$ & $80 \%$ & $100 \%$ \\
\hline STS & TS & CS & S & SS
\end{tabular}

Dari range kategori tersebut dapat dilihat bahwa dari hasil distribusi persentase jawaban berdasarkan variabel niat untuk menggunakan adalah sebesar 76,66\% menyatakan sukses dan $23,34 \%$ menyatakan tidak sukses. 
Dari hasil tersebut dapat diartikan responden setuju bahwa dosen dan mahasiswa/i memiliki keinginan dalam menggunakan sistem $e$-learning untuk proses perkuliahan.

2. Variabel Persepsi Kemudahan Pengguna menggunakan terdiri dari 2 butir pertanyaan, berikut ini adalah tabel distribusi frekuensi variabel Persepsi Kemudahan menggunakan berdasarkan hasil pengumpulan kuesioner yang sudah diolah terdapat pada Tabel 6.

TABEL VI

PertanyaAn Persepsi Kemudahan PengGunAan

\begin{tabular}{|c|c|c|c|c|c|c|}
\hline \multirow[t]{2}{*}{ No } & Persepsi kemudahan penggunaan & STS & TS & $\mathrm{CS}$ & $S$ & SS \\
\hline & (Perceived Ease Of Use) & 1 & 2 & 3 & 4 & 5 \\
\hline 1 & $\begin{array}{l}\text { Mudah bagi saya untuk menjadi } \\
\text { ahli dalam mengoperasikan } \\
\text { sistem E-learning }\end{array}$ & 2 & 10 & 9 & 8 & 1 \\
\hline 2 & $\begin{array}{l}\text { Mengoperasikan sistem } E- \\
\text { learning sangat jelas dan mudah } \\
\text { dipahami }\end{array}$ & 0 & 4 & 15 & 9 & 2 \\
\hline
\end{tabular}

Maka dilakukan analisis dengan metode likert untuk mendapatkan range kategori. Dari perhitungan metode likert didapatkan range kategori variabel niat untuk berperilaku, adapun range kategorinya dapat dilihat pada Tabel 7.

TABEL VII

RANGE VARIABEl PERSEPSI KEMUdAHAN PENGGUNA

\begin{tabular}{|c|c|c|r|rr|r|}
0 & $20 \%$ & $40 \%$ & $60 \%$ & $\mathbf{6 1 , 6 6 \%}$ & $80 \%$ & $100 \%$ \\
\hline STS & TS & CS & S & SS \\
\hline
\end{tabular}

Dari range kategori tersebut dapat dilihat bahwa dari hasil distribusi persentase jawaban berdasarkan variabel niat untuk menggunakan adalah sebesar $61,66 \%$ menyatakan sukses dan 38,34\% menyatakan tidak sukses. Dari hasil tersebut dapat diartikan responden setuju bahwa mahasiswa/i memiliki keinginan dalam menggunakan sistem e-learning untuk proses perkuliahan

3. Variabel sikap terhadap pengguna terdiri dari 2 butir pertanyaan, berikut ini adalah tabel distribusi frekuensi variabel sikap terhadap pengguna berdasarkan hasil pengumpulan kuesioner yang sudah diolah terdapat pada Tabel 8 .

TABEL VIII

PERTANYAAN SIKAP TERHADAP PENGGUNAAN

\begin{tabular}{|c|l|c|c|c|c|c|}
\hline No & $\begin{array}{l}\text { Sikap Terhadap Penggunaan STS } \\
\text { (Attitude Toward Using) }\end{array}$ & 1 & 2 & 3 & 4 & 5 \\
\hline 1 & $\begin{array}{l}\text { Saya sangat menyukai } \\
\text { pembelajaran menggunakan } \\
\text { sistem E-learning }\end{array}$ & 0 & 6 & 11 & 10 & 3 \\
\hline 2 & $\begin{array}{l}\text { Menggunakan penerapan sistem } \\
\text { E-learning sangat bagus dalam } \\
\text { belajar mengajar }\end{array}$ & 0 & 1 & 12 & 11 & 6 \\
\hline
\end{tabular}

Maka dilakukan analisis dengan metode likert untuk mendapatkan range kategori. Dari perhitungan metode likert didapatkan range kategori variabel niat untuk berperilaku, adapun range kategorinya dapat dilihat pada Tabel 9.

TABEL IX

RANGE VARIABEL SIKAP TERHADAP PENGGUNA

\begin{tabular}{|l|l|l|r|rr|r|}
$20 \%$ & $40 \%$ & $60 \%$ & $\mathbf{7 0 , 6 6 \%}$ & $80 \%$ & $100 \%$ \\
\hline STS & TS & CS & S & SS
\end{tabular}

Dari range kategori tersebut dapat dilihat bahwa dari hasil distribusi persentase jawaban berdasarkan variabel sikap untuk menggunakan adalah sebesar 70,66\% menyatakan sukses dan 29,34\% menyatakan tidak sukses. Dari hasil tersebut dapat diartikan responden setuju bahwa mahasiswa/i memiliki keinginan dalam menggunakan sistem e-learning untuk proses perkuliahan.

4. Variabel Pemakai Actual menggunakan terdiri dari 2 butir pertanyaan, berikut ini adalah tabel distribusi frekuensi variabel Pemakai Actual berdasarkan hasil pengumpulan kuesioner yang sudah diolah terdapat pada Tabel 10 berikut ini :

TABEL $X$

PERTANYAAN PEMAKAI ACTUAL

\begin{tabular}{|c|l|c|c|c|c|c|}
\hline No & Pemakai actual (Actual Use) & STS & TS & CS & S & SS \\
\hline 1 & $\begin{array}{l}\text { Saya akan terus menggunakan } \\
\text { sistem E-learning dalam belajar } \\
\text { mengajar }\end{array}$ & 2 & 8 & 8 & 12 & 0 \\
\hline 2 & $\begin{array}{l}\text { Saya akan lebih sering } \\
\text { menggunakan sistem E-learning } \\
\text { dalam belajar mengajar }\end{array}$ & 4 & 7 & 11 & 7 & 1 \\
\hline
\end{tabular}

Maka dilakukan analisis dengan metode likert untuk mendapatkan range kategori. Dari perhitungan metode likert didapatkan range kategori variabel niat untuk berperilaku, adapun range kategorinya dapat dilihat pada Tabel 11.

TABEL XI

RANGE VARIABEL PEMAKAI ACTUAL

\begin{tabular}{|c|c|c|cc|c|c|}
0 & $20 \%$ & $40 \%$ & $\mathbf{5 8 , 0 0} \%$ & $60 \%$ & $80 \%$ & $100 \%$ \\
\hline STS & TS & CS & S & SS
\end{tabular}

Dari range kategori tersebut dapat dilihat bahwa dari hasil distribusi persentase jawaban berdasarkan variabel Pemakai Actual untuk menggunakan adalah sebesar $58,00 \%$ menyatakan sukses dan $42,00 \%$ menyatakan tidak sukses. Dari hasil tersebut dapat diartikan responden cukup setuju bahwa mahasiswa/i memiliki keinginan dalam menggunakan sistem e-learning untuk proses perkuliahan.

5. Variabel keseluruhan dari metode TAM dalam pengukuran kesuksesan dan penggunaan sistem $e$ learning berdasarkan variabel, kemudian peneliti melakukan perhitungan tingkat persentase pengukuran seluruh variabel pada metode TAM, dapat dilihat pada Tabel 12.

TABEL XII

DISTRIBUSI FREKUENSI VARIABEL KESELURUHAN TAM

\begin{tabular}{|r|l|c|r|r|}
\hline No & Jawaban & $\begin{array}{r}\text { Skala } \\
\text { Likert }\end{array}$ & $\begin{array}{r}\text { Freku } \\
\text { ensi }\end{array}$ & $\begin{array}{r}\text { Persentase } \\
\text { \% }\end{array}$ \\
\hline 1 & Sangat Tidak Setuju & 1 & 8 & 3 \\
\hline 2 & Tidak Setuju & 2 & 39 & 16 \\
\hline 3 & Cukup Setuju & 3 & 83 & 35 \\
\hline 4 & Setuju & 4 & 84 & 35 \\
\hline 5 & Sangat Setuju & 5 & 26 & 11 \\
\hline \multicolumn{2}{|l|}{ Total } & 240 & 100 \\
\hline \multicolumn{2}{|l|}{ Jumlah skor dari hasil penelitian } & 801 & \\
\hline
\end{tabular}


Maka dilakukan analisis dengan metode likert untuk mendapatkan range kategori. Dari perhitungan metode likert didapatkan range kategori variabel keseluruhan, adapun range kategorinya dapat dilihat pada Tabel 13. TABEL XIII

RANGe VARIABEL KeSELURUHAN TAM

0 \begin{tabular}{|l|l|r|rr|l|}
$20 \%$ & $40 \%$ & $60 \%$ & $\mathbf{6 6 , 7 5 \%}$ & $80 \%$ & $100 \%$ \\
\hline STS & TS & CS & S & SS
\end{tabular}

Dari range kategori tersebut dapat dilihat bahwa dari hasil distribusi persentase jawaban berdasarkan variabel Pemakai Actual untuk menggunakan adalah sebesar $66,75 \%$ menyatakan sukses dan 33,25\% menyatakan tidak sukses. Dari hasil tersebut dapat diartikan responden setuju bahwa mahasiswa/i memiliki keinginan dalam menggunakan sistem e-learning untuk proses perkuliahan.

Metode UTAUT menggunakan 5 variabel untuk melakukan pengukuran penerimaan kesuksesan dengan kuesioner sesuai dengan variabel pertanyaan sebagai berikut :

1. Variabel Ekspektasi kinerja terdiri dari 2 butir pernyataan, berikut ini adalah tabel distribusi frekuensi variabel ekspektasi kinerja berdasarkan Pertanyaan hasil pengumpulan kuesioner yang sudah diolah terdapat pada Tabel 14.

TABEL XIV

PERTANYAAN PERSEPSI EKSPEKTASI KINERJA

\begin{tabular}{|c|l|c|c|c|c|c|c|}
\hline No & $\begin{array}{l}\text { Ekspektasi Kinerja } \\
\text { (Performance Expectancy) }\end{array}$ & 1 & 2 & 3 & 4 & 5 \\
\hline 1 & $\begin{array}{l}\text { Sistem E-learning dapat } \\
\text { membantu dalam kegiatan belajar } \\
\text { mengajar }\end{array}$ & 0 & 0 & 3 & 19 & 8 \\
\hline 2 & $\begin{array}{l}\text { Sistem E-learning dapat } \\
\text { meningkatkan kualitas belajar } \\
\text { mengajar }\end{array}$ & 0 & 0 & 8 & 15 & 7 \\
\hline
\end{tabular}

Maka dilakukan analisis dengan metode likert untuk mendapatkan range kategori. Dari perhitungan metode likert didapatkan range kategori variabel ekspektasi kinerja, adapun range kategorinya dapat dilihat pada Tabel 15.

TABEL XV

VARIABEL EKSPEKTASI KINERJA

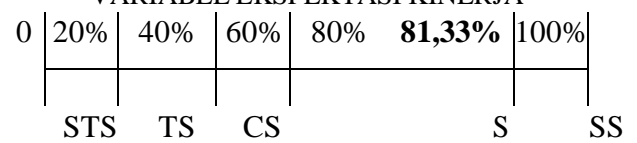

Dari range kategori tersebut dapat dilihat bahwa dari hasil distribusi persentase jawaban berdasarkan variabel ekspektasi kinerja adalah sebesar $81,33 \%$ menyatakan sukses dan 18,67\% menyatakan tidak sukses. Dari hasil tersebut dapat diartikan bahwa responden setuju bahwa menggunakan sistem e-learning dapat membantu dan memudahkan mahasiswa/i dalam proses perkuliahan di Universitas ZZP Yogyakarta.

2. Variabel Ekspektasi Usaha terdiri dari 2 butir pernyataan, berikut ini adalah tabel distribusi frekuensi variabel ekspektasi usaha berdasarkan pertanyaan hasil pengumpulan kuesioner yang sudah diolah terdapat pada Tabel 16.
TABEL XVI

PERTANYAAN PERSEPSI EKSPEKTASI USAHA

\begin{tabular}{|c|l|c|c|c|c|c|}
\hline No & $\begin{array}{l}\text { Ekspektasi Usaha } \\
\text { (Effort Expectancy) }\end{array}$ & $\begin{array}{c}\text { STS } \\
1\end{array}$ & $\begin{array}{c}\text { TS } \\
2\end{array}$ & $\begin{array}{c}\text { CS } \\
\text { S }\end{array}$ & $\begin{array}{c}\text { S } \\
4\end{array}$ \\
\hline 1 & $\begin{array}{l}\text { Menurut saya sistem E-learning } \\
\text { mudah digunakan }\end{array}$ & 0 & 1 & 15 & 12 & 2 \\
\hline 2 & $\begin{array}{l}\text { Fitur-fitur dalam E-learning } \\
\text { memberikan kemudahan dalam } \\
\text { kegiatan belajar mengajar }\end{array}$ & 0 & 0 & 17 & 10 & 3 \\
\hline
\end{tabular}

Maka dilakukan analisis dengan metode likert untuk mendapatkan range kategori. Dari perhitungan metode likert didapatkan range kategori variabel ekspektasi usaha, adapun range kategorinya dapat dilihat pada Tabel 17. TABEL XVII RANGE VARIABEL EKSPEKTASI USAHA

\begin{tabular}{|c|c|c|cc|c|c|}
0 & $20 \%$ & $40 \%$ & $60 \%$ & $\mathbf{7 0 , 3 3 \%}$ & $80 \%$ & $100 \%$ \\
\hline STS & TS & CS & & S & SS
\end{tabular}

Dari range kategori tersebut dapat dilihat bahwa dari hasil distribusi persentase jawaban berdasarkan variabel ekspektasi usaha adalah sebesar 70,33\% menyatakan sukses dan 29,67\% menyatakan tidak sukses. Dari hasil tersebut dapat diartikan bahwa responden setuju bahwa menggunakan sistem e-learning memiliki kemudahan sehingga responden berminat untuk menggunakan sistem e-learning dalam proses perkuliahan.

3. Variabel Pengaruh Sosial terdiri dari 2 butir pernyataan, berikut ini adalah tabel distribusi frekuensi variabel pengaruh sosial berdasarkan hasil pengumpulan kuesioner yang sudah diolah terdapat pada Tabel 18. TABEL XVIII

PERTANYAAN PERSEPSI PENGARUH SOSIAL

\begin{tabular}{|c|c|c|c|c|c|c|}
\hline No & $\begin{array}{l}\text { Pengaruh Sosial } \\
\text { (Social Influence) }\end{array}$ & $\begin{array}{c}\text { STS } \\
1 \\
\end{array}$ & $\begin{array}{c}\mathrm{TS} \\
2\end{array}$ & $\begin{array}{c}\mathrm{CS} \\
3\end{array}$ & $\begin{array}{l}S \\
4\end{array}$ & $\begin{array}{c}\text { SS } \\
5\end{array}$ \\
\hline 1 & $\begin{array}{lcc}\text { Dosen } & \text { mengharuskan } \\
\text { menggunakan } & \text { sistem } \quad E- \\
\text { learning } & & \\
\end{array}$ & 4 & 9 & 6 & 10 & 1 \\
\hline 2 & $\begin{array}{l}\text { Dengan adanya sistem } E- \\
\text { learning membuat saya menjadi } \\
\text { lebih percaya diri dalam } \\
\text { kegiatan belajar mengajar }\end{array}$ & 0 & 6 & 12 & 12 & 0 \\
\hline
\end{tabular}

Maka dilakukan analisis dengan metode likert untuk mendapatkan range kategori. Dari perhitungan metode likert didapatkan range kategori variabel pengaruh sosial, adapun range kategorinya dapat dilihat pada Tabel 19. TABEL XIX

RANGE VARIABEL PENGARUH SOSIAL

\begin{tabular}{|l|l|l|ll|l|l|}
0 & $20 \%$ & $40 \%$ & $60 \%$ & $\mathbf{6 0 , 3 3 \%}$ & $80 \%$ & $100 \%$ \\
\hline STS & TS & CS & S & SS
\end{tabular}

Dari range kategori tersebut dapat dilihat bahwa dari hasil distribusi persentase jawaban penulis berdasarkan variabel pengaruh sosial adalah sebesar $60,33 \%$ menyatakan sukses dan 39,67\% menyatakan tidak sukses. Dari hasil tersebut termasuk kedalam kategori setuju. Dapat diartikan bahwa responden mendapat pengaruh sosial, seperti pihak kampus ataupun dari dosen dalam menggunakan sistem e-learning sebagai proses perkuliahan di Universitas ZZP Yogyakarta.

4. Variabel Kondisi-kondisi Pemfasilitasi terdiri 
dari 2 butir pernyataan, berikut ini adalah tabel distribusi frekuensi variabel kondisi pemfasilitasi berdasarkan hasil pengumpulan kuesioner yang sudah diolah terdapat pada Tabel 20 .

TABEL XX

PERTANYAAN PERSEPSI KONDISI-KONDISI PEMFASILITASI

\begin{tabular}{|l|l|c|c|c|c|c|}
\hline No & $\begin{array}{l}\text { Kondisi-Kondisi Pemfasilitasi } \\
\text { (Facilitating Conditions) }\end{array}$ & 1 & 2 & 3 & 4 & 5 \\
\hline 1 & $\begin{array}{l}\text { Saya memiliki pengetahuan } \\
\text { yang diperlukan untuk } \\
\text { menggunakan sitem E-learning }\end{array}$ & 1 & 8 & 6 & 14 & 1 \\
\hline 2 & $\begin{array}{l}\text { Saya meminta bantuan orang } \\
\text { lain saat saya mengalami } \\
\text { kesulitan menggunakan E- } \\
\text { learning }\end{array}$ & 2 & 1 & 6 & 16 & 5 \\
\hline
\end{tabular}

Maka dilakukan analisis dengan metode likert untuk mendapatkan range kategori. Dari perhitungan metode likert didapatkan range kategori variabel kondisi pemfasilitasi, adapun range kategorinya dapat dilihat pada Tabel 21.

TABEL XXI

RANGE VARIABEL KONDISI PEMFASILITASI

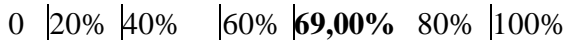

\begin{tabular}{|l|l|r|rr|l|}
\hline STS & TS & CS & & S & SS
\end{tabular}

Dari range kategori tersebut dapat dilihat bahwa dari hasil distribusi persentase jawaban berdasarkan variabel adalah sebesar $69,00 \%$ menyatakan sukses dan 31,00\% menyatakan tidak sukses. Dari hasil tersebut dapat diartikan responden setuju bahwa kondisi pemfasilitasi seperti infrastruktur yang tersedia sangat dibutuhkan untuk pemakaian sistem e-learning.

5. Variabel Niat Untuk Berperilaku terdiri dari 2 butir pernyataan, berikut ini adalah tabel distribusi frekuensi variabel niat untuk berperilaku berdasarkan hasil pengumpulan kuesioner yang sudah diolah terdapat pada Tabel 22.

TABEL XXII

PERTANYAAN PERSEPSI NIAT UNTUK BERPERILAKU

\begin{tabular}{|c|l|c|c|c|c|c|}
\hline No & $\begin{array}{l}\text { Niat Untuk Berperilaku } \\
\text { (Behavioral Intention) }\end{array}$ & $\begin{array}{c}\text { STS } \\
1\end{array}$ & $\begin{array}{c}\text { TS } \\
2\end{array}$ & $\begin{array}{c}\text { CS } \\
\text { Sela }\end{array}$ & $\begin{array}{c}\text { SS } \\
5\end{array}$ \\
\hline 1 & $\begin{array}{l}\text { Saya selalu menggunakan } \\
\text { sistem E-Learning dalam } \\
\text { kegiatan belajar mengajar }\end{array}$ & 2 & 7 & 11 & 9 & 1 \\
\hline 2 & $\begin{array}{l}\text { Saya senang menggunakan } \\
\text { sistem E-Learning dalam } \\
\text { kegiatan belajar mengajar }\end{array}$ & 0 & 4 & 12 & 11 & 3 \\
\hline
\end{tabular}

Maka dilakukan analisis dengan metode likert untuk mendapatkan range kategori. Dari perhitungan metode likert didapatkan range kategori variabel niat untuk berperilaku, adapun range kategorinya dapat dilihat pada Tabel 23.

TABEL XXIII

RANGE VARIABEL NIAT UNTUK BERPERILAKU

$$
\begin{array}{r|r|r|r|rr|r|}
0 & 20 \% & 40 \% & 60 \% & \mathbf{6 4 , 3 3 \%} & 80 \% & 100 \% \\
\hline \text { STS } & \text { TS } & \text { CS } & & \text { S } & \text { SS } \\
\hline
\end{array}
$$

Dari range kategori tersebut dapat dilihat bahwa dari hasil distribusi persentase jawaban berdasarkan variabel niat untuk menggunakan adalah sebesar 64,33\% menyatakan sukses dan $35,67 \%$ menyatakan tidka sukses. Dari hasil tersebut dapat diartikan responden setuju bahwa mahasiswa/i memiliki keinginan dalam menggunakan sistem e-learning untuk proses perkuliahan.

6. Variabel keseluruhan dari metode UTAUT dalam pengukuran kesuksesan dan penggunaan sistem $e$ learning berdasarkan variabel, kemudian peneliti melakukan perhitungan tingkat persentase pengukuran seluruh variabel pada metode UTAUT, dapat dilihat pada Tabel 24.

TABEL XXIV

DISTRIBUSI FREKUENSI VARIABEL KESELURUHAN DARI UTAUT

\begin{tabular}{|r|l|c|r|r|}
\hline No & Jawaban & $\begin{array}{r}\text { Skala } \\
\text { Likert }\end{array}$ & $\begin{array}{r}\text { Freku } \\
\text { ensi }\end{array}$ & $\begin{array}{r}\text { Persentase } \\
\text { \% }\end{array}$ \\
\hline 1 & Sangat Tidak Setuju & 1 & 9 & 3 \\
\hline 2 & Tidak Setuju & 2 & 36 & 12 \\
\hline 3 & Cukup Setuju & 3 & 96 & 32 \\
\hline 4 & Setuju & 4 & 128 & 43 \\
\hline 5 & Sangat Setuju & 5 & 31 & 10 \\
\hline \multicolumn{2}{|l|}{ Total } & 300 & 100 \\
\hline \multicolumn{2}{|l|}{ Jumlah skor dari hasil penelitian } & 1045 & \\
\hline
\end{tabular}

Maka dilakukan analisis dengan metode likert untuk mendapatkan range kategori. Dari perhitungan metode likert didapatkan range kategori variabel keseluruhan, adapun range kategorinya dapat dilihat pada Tabel 25. TABEL XXV

RANGE VARIABEL KESELURUHAN UTAUT

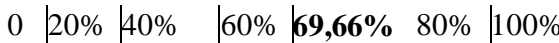

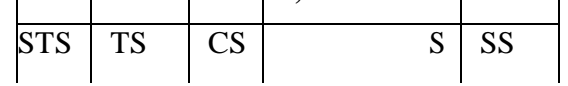

Dari range kategori tersebut dapat dilihat bahwa dari hasil distribusi persentase jawaban berdasarkan variabel Pemakai Actual untuk menggunakan adalah sebesar $69,66 \%$ menyatakan sukses dan 30,34\% menyatakan tidak sukses. Dari hasil tersebut dapat diartikan responden setuju bahwa mahasiswa/i memiliki keinginan dalam menggunakan sistem e-learning untuk proses perkuliahan.

7. Variabel keseluruhan Setelah mengetahui tingkat persentase penerimaan dan penggunaan sistem $e$ learning berdasarkan variabel, kemudian peneliti melakukan perhitungan tingkat persentase penerimaan dan penggunaan sistem e-learning secara keseluruhan, dapat dilihat pada Tabel 26.

TABEL XXVI

DISTRIBUSI FREKUENSI VARIABEL KESELURUHAN DARI TAM DAN UTAUT

\begin{tabular}{|r|l|c|r|r|}
\hline No & Jawaban & $\begin{array}{r}\text { Skala } \\
\text { Likert }\end{array}$ & $\begin{array}{r}\text { Frekue } \\
\text { nsi }\end{array}$ & Persentase \% \\
\hline 1 & Sangat Tidak Setuju & 1 & 17 & 3 \\
\hline 2 & Tidak Setuju & 2 & 75 & 14 \\
\hline 3 & Cukup Setuju & 3 & 179 & 33 \\
\hline 4 & Setuju & 4 & 212 & 39 \\
\hline 5 & Sangat Setuju & 5 & 57 & 11 \\
\hline \multicolumn{2}{|c|}{ Total } & 540 & 100 \\
\hline \multicolumn{2}{|c|}{$\begin{array}{l}\text { Jumlah skor dari hasil } \\
\text { penelitian }\end{array}$} & 1837 & \\
\hline
\end{tabular}


Maka dilakukan analisis dengan metode likert untuk mendapatkan range kategori. Dari perhitungan metode likert didapatkan range kategori variabel keseluruhan, adapun range kategorinya dapat dilihat pada Tabel 27.

TABEL XXVII

RANGE VARIABEL KeSELURUHAN TAM

\begin{tabular}{|r|r|r|r|rr|r|}
0 & $20 \%$ & $40 \%$ & $60 \%$ & $\mathbf{6 8 , 0 3 \%}$ & $80 \%$ & $100 \%$ \\
\hline STS & TS & CS & S & SS
\end{tabular}

Dari range kategori tersebut dapat dilihat bahwa dari hasil distribusi persentase jawaban berdasarkan variabel keseluruhan adalah sebesar 68,03\% menyatakan dapat diterima dan $31,07 \%$ responden tidak menyatakan kesuksesan terhadap implementasi e-learning. Dari hasil tersebut dapat disimpulkan bahwa variabel ekspektasi kinerja, ekspektasi usaha, pengaruh sosial, kondisi pemfasilitasi, niat untuk berperilaku, persepsi kemanfaatan, kemudahan pengguna, sikap terhadap pengguna, pemakai actual dapat diterima oleh responden.

\section{KESIMPULAN}

Berdasarkan hasil penelitian dan pembahasan mengenai kajian tentang pengukuran kesuksesan implementasi $e$ learning dengan metode TAM dan UTAUT, maka dapat disimpulkan sebagai berikut :

Hasil penelitian menunjukkan bahwa pada metode TAM, berdasarkan hasil menunjukkan bahwa variabel kebermanfaatan yang paling berpengaruh atau lebih kuat dalam menjelaskan kesuksesan penerapan sistem $e$ learning. Hal ini berarti bahwa sistem e-learning telah sukses diterapkan sebab memiliki banyak kegunaan dalam membantu proses perkuliahan mahasiswa/i. Sedangkan pada metode UTAUT variabel ekspektasi kinerja yang paling berpengaruh atau lebih kuat dalam menjelaskan kesuksesan penerapan sistem informasi akademik. Hal ini berarti bahwa sistem informasi akademik yang diterapkan memiliki performace yang dapat diandalkan guna membantu proses perkuliahan serta sistem e-learning tersebut sudah berjalan diatas infrastruktur yang memadai serta didukung oleh sarana dan prasarana pendukung sistem.

Sedangkan pengukuran dengan metode TAM dan UTAUT dalam penerapan sistem e-learning dapat dilihat pada hasil uji. Dari hasil tersebut dapat disimpulkan bahwa metode UTAUT merupakan metode yang paling baik digunakan dalam studi kasus ini sebab metode UTAUT mampu mengukur sebanyak 69,66\% menyatakan sukses dan 30,34\% menyatakan tidak sukses. dari aspekaspek yang dapat digunakan untuk menilai kesuksesan penerapan sebuah sistem e-learning dan metode TAM hanya mampu mengukur sebanyak $66,75 \%$ menyatakan sukses dan 33,25\% menyatakan tidak sukses.

Sehingga pengukuran kesuksesan menggunakan ke2(dua) metode dengan persentase sebanyak 68,03\% menyatakan sukses dan $31,07 \%$ tidak menyatakan kesuksesan dalam penerapan sistem e-learning, sehingga dapat diartikan besarnya tingkat penerimaan kesuksesan dan penggunaan metode TAM dan UTAUT berpengaruh terhadap minat menggunakan sistem e-learning pada Fakultas Ekonomi Universitas ZZP Yogyakarta.

\section{REFERENSI}

[1] M. Prof.dr. Soliyanto, SE, "Metode Penelitian Kuantitatif," pp. 139, 2017.

[2] S. Anshori, "Strategi pembelajaran di era digital (tantangan profesionalisme guru di era digital)," Artikel, vol. Strategi P, no. Strategi Pemilihan Media Pembelajaran Bagi Seorang Guru, pp. 194-202, 2016.

[3] N. S. Hanum, "Keefetifan e-learning sebagai media pembelajaran (studi evaluasi model pembelajaran e-learning SMK Telkom Sandhy Putra Purwokerto)," J. Pendidik. Vokasi, vol. 3, no. 1, pp. 90-102, 2013.

[4] H. Pamugar, W. W. Winarno, and W. Najib, "Model Evaluasi Kesuksesan dan Penerimaan Sistem Informasi E-Learning pada Lembaga Diklat Pemerintah,” Sci. J. Informatics, vol. 1, no. 1, pp. 13-27, 2014.

[5] I. Mutia and L. Leonard, "Kajian penerapan e-learning dalam proses pembelajaran di perguruan tinggi," Fakt. Exacta, vol. 6, no. 4, pp. 278-289, 2013.

[6] K. M. R. Alditra, A. Yudhana, and R. Umar, "Membangun Rancangan Sistem Informasi Menggunakan Berbasis Web Mobile ( Studi Kasus: Toko Kgs Rizky Motor )," Semin. Nas. Inform., vol. 2018, no. semnasIF, pp. 92-95, 2018

[7] M. T. Informatika, U. Ahmad, and D. Yogyakarta, "Analisis kepuasan pengguna sistem informasi E-Government menggunakan metode WEBQUAL 4.0," vol. 3, no. 2, pp. 127 $135,2019$.

[8] R. Umar and Yudhana, "Desain Antar Muka Sistem e-Learning Berbasis Web," Query, vol. 5341, no. April, pp. 33-40, 2018.

[9] D. Nugraheni, M. C. Saputra, and A. D. Herlambang, "Analisis Penerimaan dan Kesuksesan Implementasi E-Learning Universitas Brawijaya Pada Aspek Intention To Use, Use, User Satisfaction dan Net Benefits," J. Pengemb. Teknol. Inf. dan Ilmu Komput. Univ. Brawijaya, vol. 2, no. 5, pp. 1921-1931, 2017.

[10] M. Jundullah, R. Umar, and A. Yudhana, "Analisis Penerimaan Sistem E-Learning Smk Negeri 4 Kota Sorong Dengan Menggunakan Technology Acceptance Model ( TAM )," Semin. Nas. Teknol. Fak. Tek. Univ. Krisnadwipayana, pp. 724-729, 2019.

[11] N. Miyono, "Analisis E-Learning Menggunakan Technology Acceptance Modelling," J. Transform., vol. 11, no. 1, p. 39, 2013.

[12] A. H. Mirza and D. Andrini, "Penerapan Metode Tam ( Technology Acceptance Model ) Terhadap E-Tracer Alumni Universitas Bina Darma," pp. 13-16, 2014.

[13] M. Ismarmiaty, "Analisis Model Penerimaan Dan Penggunaan Sistem Informasi Website Padamu Negeri Oleh Pengguna Menggunakan Model Unified Theory Of Acceptance And Use Of Technology (Utaut)," J. Matrik, vol. 16, no. 1, p. 77, 2017.

[14] I. G. N. Sedana and S. W. Wijaya, "Penerapan Model Utaut Untuk Memahami Penerimaan Dan Penggunaan Learning Management System Studi Kasus: Experential E-Learning of Sanata Dharma University,” J. Sist. Inf., vol. 5, no. 2, p. 114, 2012.

[15] L. Thoifah, "statistik pendidikan dan metode penelitian kuantitatif," Malang : Madani, 2015.

[16] . prof.dr.suliyanto, SE, MM, "metode penelitian kuantitatif," pp. $1-20,2017$

[17] E. Rimawati and W. L. Y. Saptomo, "Analisis Diskriptif Technologi Acceptance Model pada Penerapan Blended Learning," J. Ilm. SINUS, vol. 17, no. 2, p. 51, 2019.

[18] E. Setiawan, D. Antoni, and A. H. Mirza, "Analisis Penerimaan Sistem Ujian Online Berbayar Dengan Menggunakan Metode Technology Acceptance Model (Tam) Dan Webqual,” J. Bina Komput., vol. 1, no. 1, pp. 61-72, 2019.

[19] M. ariandi Fatmasari, "MANFAAT FASILITAS KRS ONLINE DENGAN METODE TECHNOLOGY ACCEPTANCE MODEL ( TAM )," pp. 1-7, 2014.

[20] R. A. Faoziah and J. Sembiring, "PENGARUH IMPLEMENTASI SISTEM PEMBELAJARAN E-LEARNING ( STUDI KASUS FAKULTAS INFORMATIKA DAN FAKULTAS REKAYASA 
INDUSTRI ) EFFECT OF IMPLEMENTATION OF ELEARNING LEARNING SYSTEM TO SATISFACTION OF UNIVERSITY STUDENTS TELKOM ( CASE STUDY FACULTY OF INFORMATI," vol. 4, no. 3, pp. 2547-2554, 2017.

[21] A. Anggoro and Arisantoso, "ANALISIS PERILAKU DARI PENERAPAN E-LEARNING SECARA TIDAK PENUH Program Studi Teknik Informatika, Fakultas Teknik, Universitas Islam Attahiriyah Assrie Anggoro , Analisis Perilaku Dari Penerapan E-Learning ...," vol. 5, no. 1, 2018.

[22] R. D. Mahande and Jasruddin, "UTAUT Model: Suatu Pendekatan Evaluasi Penerimaan E-Learning pada Program Pascasarjana," 2016.

[23] A. A. Rahman, "Penerapan model UNIFIED THEORY OF ACEPTANCE AND USE OF TECHNOLOGY (UTAUT)," pp. 7-15, 2016.

[24] Fatmasari, "Evaluasi penerapan frofast menggunakan model utaut," J. FK UMP, vol. 1, no. 1, pp. 36-41, 2018 .
[25] W. Budiaji, "Skala Pengukuran dan Jumlah Respon Skala Likert (The Measurement Scale and The Number of Responses in Likert Scale)," Ilmu Pertan. dan Perikan., vol. 2, no. 2, pp. 127-133, 2013.

[26] M. I. Ukkas, H. Ekawati, and T. Riandi, "Skala Likert Dalam Seleksi Karyawan Baru Dengan Metode Fuzzy Tsukamoto Berbasis Web ( Studi Kasus: Pt Telkom Akses Area Samarinda ),"S Sebatik, vol. 22, no. 2, pp. 211-218, 2018. 